\title{
RELATION OF SERUM CALCIUM TO SERUM ALBUMIN AND GLOBULINS
}

\author{
By ALEXANDER B. GUTMAN AND ETHEL BENEDICT GUTMAN \\ (From the Department of Medicine, College of Physicians and Surgeons, Columbia University \\ and the Presbyterian Hospital, New York City)
}

(Received for publication July 9, 1937)

In 1923, Salvesen and Linder (1) pointed out that hypoproteinemia in the nephrotic type of Bright's disease is associated with hypocalcemia, the calcium content of the serum tending to parallel the total serum protein level. Marrack and Thacker (2) and Hastings, Murray and Sendroy (3) subsequently expressed this proportionality between total calcium and total protein more precisely in the form of an empirical regression equation. By plotting the calcium content of body fluids of low or normal protein content as ordinates against the respective total protein values, they showed that the points so obtained approximate a straight line which has a positive slope and intersects the " $\mathrm{y}$ " $(\mathrm{Ca})$ axis at a point above the origin. Such a linear relation, since confirmed in nephrotic and normal sera by others $(4,5,6)$, may be expressed by the general regression equation (5):

$$
\text { Total } \mathrm{Ca}=m \cdot \text { total protein }+b,
$$

where $m$, the slope of the line, is a constant which defines the amount of calcium bound per unit total protein

and $b$, the intercept on the " $\mathrm{y}$ " axis, is a constant which defines the amount of calcium not bound to protein.

Though derived from clinical data, and purely empirical, Equation I is in accord with deductions drawn from dialysis and ultrafiltration experiments. These indicate that calcium present in serum is partly in a non-diffusible, partly in a diffusible state. At physiological concentrations of $\mathrm{Ca}^{++}, \mathrm{PO}_{4}^{-}$and $\mathrm{H}^{+}$, the non-diffusible calcium fraction appears to be protein-bound calcium; and values obtained for the diffusible calcium fraction, which is composed largely of $\mathrm{Ca}^{++}(7,8)$, are in satisfactory agreement with values obtained for $b$. McLean and Hastings (5) have shown, further, that Equation I may be derived from a general mass law equation for the dissociation of calcium proteinate where the protein molecules are assumed to be composed of a series of negatively charged divalent ions :

$$
\frac{\left[\mathrm{Ca}^{++}\right] \cdot[\text { Prot. }--]}{[\text { Ca Prot. }]}=K \text {. }
$$

Substituting [Total Prot.] - [Ca Prot.] for [Prot.--] and simplifying, we obtain:

$$
\frac{\left[\mathrm{Ca}^{++}\right] \cdot[\text { Total Prot. }]}{[\mathrm{Ca} \text { Prot. }]}=K+\left[\mathrm{Ca}^{++}\right] \text {. }
$$

Substituting [Total Ca] $-\left[\mathrm{Ca}^{++}\right]$for $[\mathrm{Ca}$ Prot.] and dividing both sides of the equation by $\left[\mathrm{Ca}^{++}\right]$, we obtain :

$$
\frac{[\text { Total Prot. }]}{[\text { Total Ca }]-\left[\mathrm{Ca}^{++}\right]}=\frac{K}{\left[\mathrm{Ca}^{++}\right]}+1 \text {. }
$$

For the special case where the concentration of $\mathrm{Ca}^{++}$is constant (and the experimental data used in deriving Equation I are restricted by definition to that condition), the constant $b$ may be substituted for $\left[\mathrm{Ca}^{++}\right]$. Designating the relation of constants $\frac{K}{b}+1$ by the reciprocal of the constant $m$, we obtain:

$$
\frac{[\text { Total Prot.] }}{\text { [Total Ca] }-b}=\frac{1}{m} \text {. }
$$

which solved for [Total Ca] gives Equation I. Equation I does not apply if there is a primary disturbance in calcium metabolism (3) nor in the presence of hyperphosphatemia $(1,4)$. But apart from these restrictions, this equation seems so well supported by both empirical and theoretical evidence that it has come to be regarded as a generally valid expression of the relation between total calcium and total serum protein.

For example, it is inferred-as follows from Equation I-that elevated calcium values are to be expected in association with hyperproteinemia. Since a significant proportion (almost half) of the total calcium in normal serum is bound to 
protein, it does seem to follow that with increased protein content there would be an increase in calcium bound to protein and, consequently, a rise in the total calcium content of the serum; hyperproteinemia being regarded in this sense as "a cause of " or " responsible for" hypercalcemia. A number of cases of multiple myeloma have been described in which hyperproteinemia was, in fact, associated with hypercalcemia. And in such cases, a definite increase in the non-diffusible (or protein-bound) calcium fraction could be demonstrated by ultrafiltration-a result in accord with the implications of Equation I.

Despite this considerable body of supporting evidence, however, empirical equations of the general form of Equation I should be regarded, as Peters and Van Slyke (9) have pointed out, only as "rough first approximations" of the relation of calcium to protein in serum. It has often been noted that when, as in hepatic cirrhosis (10), decreased serum albumin is associated with increased serum globulin, the serum calcium level seems to parallel the albumin rather than the total serum protein content. Such observations led Schmidt and Greenberg (11) to conclude that " because the protein bound calcium probably is very largely united to the albumin rather than to the total protein, the total protein content of the serum can only give an inadequate representation."

Our own data indicate that in a variety of diseases presenting hyperglobulinemia, there is a serious discrepancy between observed serum calcium and that calculated by formulae based upon Equation I $(6,12)$. It would appear that Equation $I$ in its present form is not generally valid (within the limitations prescribed above), as has been assumed. Analysis of our data suggests further that a more satisfactory approximation could be effected by an expression relating calcium specifically to the several protein fractions of which the total serum protein is composed. A definitive equation of this kind is not attainable for the present because of the prevailing uncertainty regarding the serum protein fractions and their calcium-binding properties under the conditions existing in serum. By graphic and statistical analysis of our data, however, we derived an equation relating total calcium to serum albumin and two arbitrarily defined serum globulin fractions. This equation appears to give better agreement between observed and calculated serum calcium over a wide range of variation in serum proteins than do equations relating total calcium to total protein, to albumin and total globulin, or to albumin alone.

\section{MATERIAL AND METHODS}

Our data (Table I) include 27 observations on 21 cases of the nephrotic syndrome, with low albumin and normal or somewhat decreased globulin levels; 20 observations on 15 normal subjects; 50 observations on 39 cases of lymphogranuloma inguinale, 37 sera containing more than 8.0 per cent total protein; 25 observations on 20 miscellaneous cases with hyperproteinemia not due to lymphogranuloma inguinale, multiple myeloma or hepatic cirrhosis; and 42 observations on 28 cases of hepatic cirrhosis, with low or normal albumin and normal or high globulin levels. With the exception of cases of extreme dehydration, which were not available for study, the data may be regarded as illustrative of the types of changes in serum proteins occurring in disease.

For reasons stated in the text, conditions in which the concentration of $\mathrm{Ca}^{++}$per unit serum water could not be assumed to be within normal limits were excluded: Cases with a primary disturbance in calcium metabolism (including multiple myeloma); cases with hyperphosphatemia; and cases with hypoproteinemia due to malnutrition or occurring in terminal stages of wasting diseases. Apart from these restrictions, and the inclusion of only a few representative normal values, the data are unselected.

Serum calcium was determined by the Clark and Collip modification of the Kramer and Tisdall method (30). Serum protein was determined by difference, total nitrogen by the Kjeldahl technique, and nonprotein nitrogen by Folin's method with nesslerization (31). Albumin and the globulin fractions were estimated by Howe's method (32), nitrogen being determined by the micro-Kjeldahl technique and titration. Inorganic phosphorus was determined by the method of Kuttner and Lichtenstein as modified by A. Bodansky (33). All determinations were carried out in duplicate, except some calcium analyses, when insufficient serum was available.

In view of the wide range in total protein content of our sera, the concentrations of all relevant solutes were expressed in terms of serum $\mathrm{H}_{2} \mathrm{O}$. This involves a correction:

$$
C_{w}=\frac{C_{s}}{W_{s}} \cdot 100
$$

where

$C_{w}=$ concentration of solute per unit weight of serum $\mathrm{H}_{2} \mathrm{O}$.

$C_{s}=$ concentration of solute per unit volume of serum. $W_{8}=$ grams of $\mathrm{H}_{2} \mathrm{O}$ per 100 cc. serum.

$W_{8}$ was calculated by the McLean and Hastings' formula (5) :

$$
W_{\mathrm{s}}=99.0-0.75 P_{\mathrm{s}},
$$


where

$P_{8}=$ grams of total protein per $100 \mathrm{cc}$. serum,

$0.75=$ the Svedberg and Sjögren factor for specific molecular volume of serum protein

and 1 per cent of serum volume is assumed to be occupied by solutes other than protein.

A quotient nomogram (Figure 1), which proved useful for rapid conversion of large groups of data and for checking values calculated in the usual manner, was constructed on the basis of the formula:

where

$$
\log x=\log y+\operatorname{colog} z
$$

$$
\begin{aligned}
& x=C_{w 0} \text { as defined above, } \\
& y=C_{8} \text { as defined above, } \\
& z=W_{8} \text { as defined above } \div 100
\end{aligned}
$$

Column $P_{8}$ represents the observed serum protein content in grams per $100 \mathrm{cc}$. serum. The columns $C_{8}$ and $C^{\prime}$ s represent the observed concentration per $100 \mathrm{cc}$. serum of that solute which is to be expressed in terms of serum water; $C_{8}$ being scaled to cover the range 1.5 to 3.0 and 3.0 to 6.0 ; the scale of $C^{\prime}{ }_{8}$ reading from 1.0 to 1.5 and from 6.0 to $10.0 .1 \mathrm{~A}$ straight line connecting the point on the $P_{s}$ column corresponding to the observed total protein content of the serum, with the point on the $C_{s}$ or $C^{\prime} s$ column corresponding to the observed concentration of solute in serum, will intersect the adjacent $C_{w}$ or the respective $C^{\prime}{ }_{w}$ column at a point representing the desired concentration of solute in serum water.

The nomogram is applicable to sera containing 3.0 to 12.0 grams of total protein per $100 \mathrm{cc}$. serum. It gives results accurate to the third significant figure over the range of variation in serum electrolytes (expressed in milligrams respectively grams, or in milliequivalents).

\section{RESULTS}

Relation of total serum calcium to total serum protein in the nephrotic syndrome and in normal subjects. In Figure 2, we have plotted values for total serum calcium against the respective total protein content of sera obtained from patients with the nephrotic syndrome. To show the trend more clearly, 4 observations on 4 cases of " healed nephrosis" and 15 representative results on normal subjects are included. The points, indicated by hollow dots, show a positive linear correlation which is in good agreement with Equation I. The straight line shown in Figure 2 was not drawn through our points but represents Equation I where $m=0.75$ and $b=5.6$, total protein being expressed in grams, total calcium in milligrams

1 To convert solute concentrations greater than 10.0, move the decimal point to conform with scales of the $C_{8}$ or $C^{\prime} s$ column and the respective $C_{w}$ or $C^{\prime}$ w column. per 100 grams serum water. These values for $m$ and $b$ are the means of the several constants obtained empirically by various investigators, as calculated by McLean and Hastings (5).

Our results, therefore, are in accord with the findings in the literature with respect to the direct proportionality between total serum calcium and total serum protein in the nephrotic syndrome and in normal subjects. As a corollary, it may be inferred that the standard methods employed in determining calcium and protein give results in our hands which are consistent with those obtained by others; and consequently the discrepancies encountered in the diseases now to be considered are not due to differences in technique.

Relation of total serum calcium to total serum protein in lymphogranuloma inguinale. As was pointed out elsewhere $(13,14)$, many cases of lymphogranuloma inguinale present hyperproteinemia, the total protein reaching levels as high as 11 grams per $100 \mathrm{cc}$. serum. Hyperproteinemia in lymphogranuloma inguinale is not, however, associated with hypercalcemia $(13,14)$. The points obtained by plotting total calcium against the respective total serum protein in our cases (Figure 2) do not fall along the straight line corresponding to Equation I. The trend shown by these points is approximately parallel to the " $x$ " axis. It would appear, therefore, that the linear relation between total serum calcium and total serum protein observed in hypoproteinemia does not obtain in hyperproteinemia due to lymphogranuloma inguinale.

Relation of total serum calcium to total serum protein in miscellaneous diseases presenting hyperproteinemia. This discrepant relation is not peculiar to hyperproteinemia occurring in lymphogranuloma inguinale. In Figure 3, we illustrate the distribution of points obtained by plotting total calcium against total serum protein in 20 miscellaneous cases presenting hyperproteinemia not due to lymphogranuloma inguinale, multiple myeloma or hepatic cirrhosis. This group is composed chiefly of various infections. In some instances, no diagnosis could be established. In several instances, lymphogranuloma inguinale was suspected clinically, but the Frei test was negative.

As in lymphogranuloma inguinale, the points do not fall along a straight line corresponding to Equation I but show a trend approximately paral- 

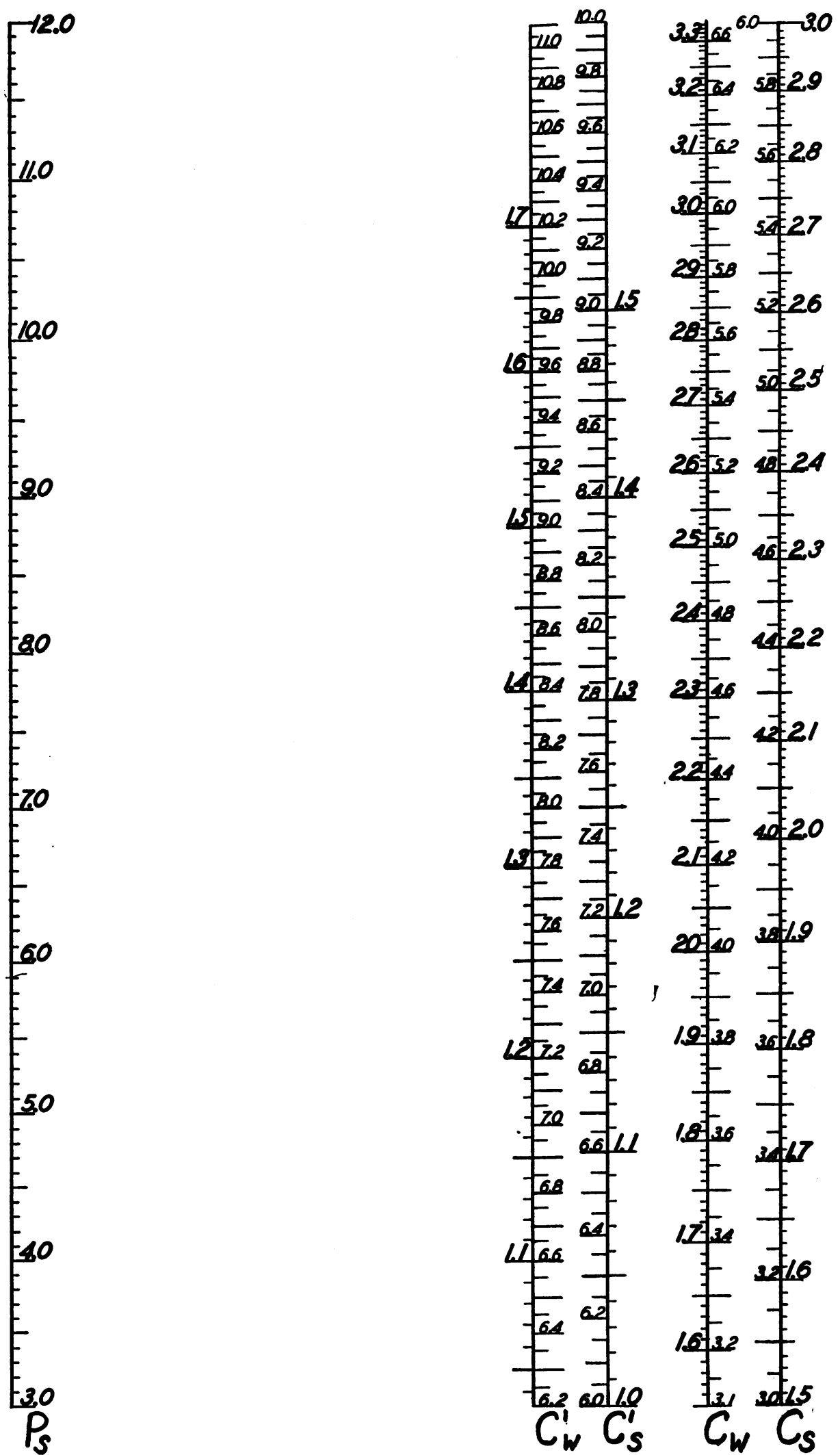

Fig. 1. Nomogram for Converting Solute Concentrations per 100 cc. Serum to Solute Concentrations per 100 Grams Serum $\mathrm{H}_{2} \mathrm{O}$ 


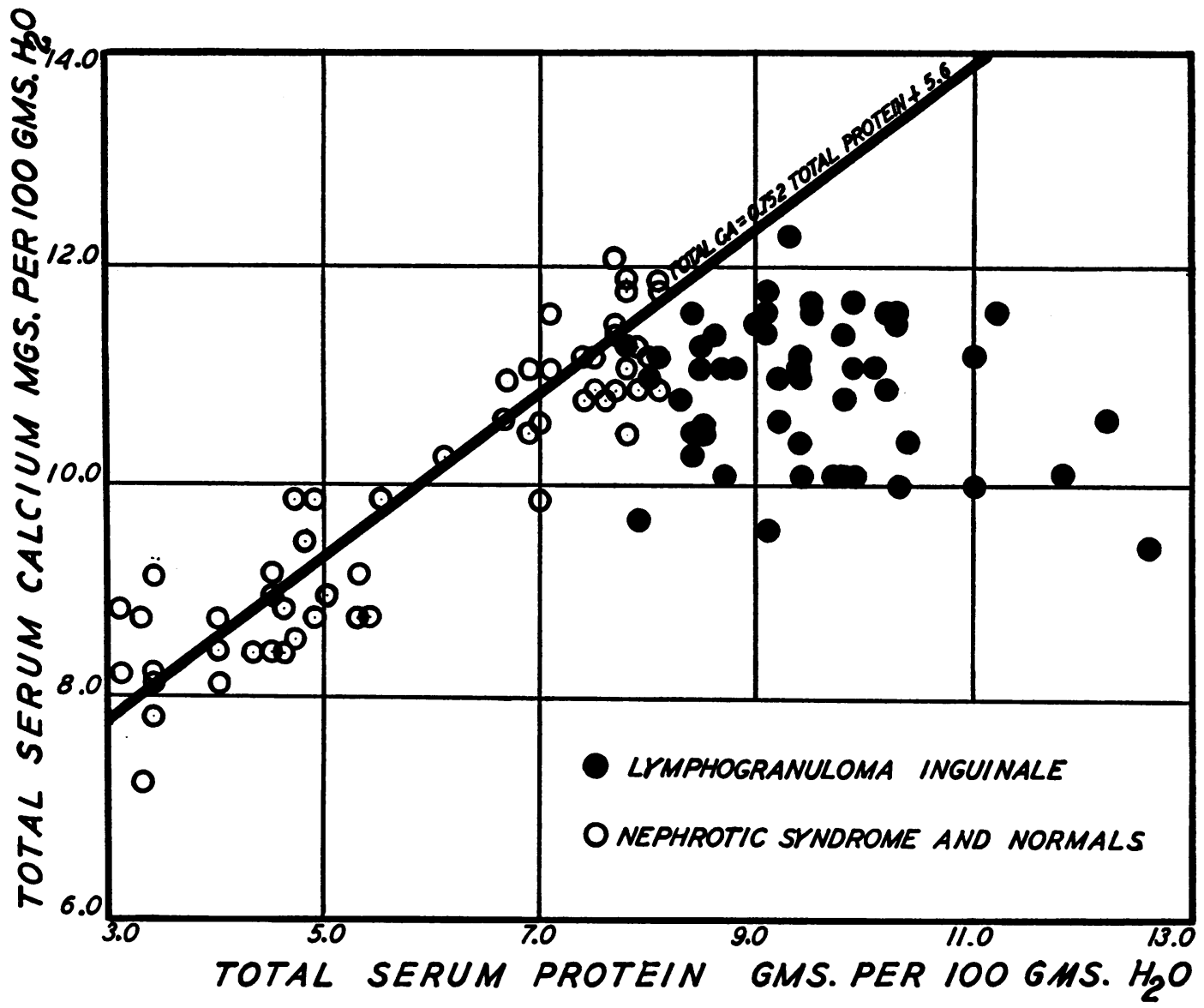

Fig. 2. Relation of Total Calcium to the Respective Total Protein Content of Sera in the Nephrotic Syndrome and in Normal Subjects, Showing a Direct Proportionality between These Two Constituents

This proportionality does not hold in hyperproteinemia due to lymphogranuloma inguinale.

lel to the " $\mathrm{x}$ " axis. Our results (Table I and Figure 3 ) indicate that, contrary to the implications of Equation I, the total serum calcium does not rise in hyperproteinemia but is maintained at normal levels. (This generalization does not apply to relative increases in serum proteins and other solutes occurring in extreme dehydration; or to conditions like multiple myeloma where there is a primary disturbance in calcium metabolism.)

Relation of total serum calcium to total serum protein in hepatic cirrhosis. Figure 3 also shows the distribution of 42 points obtained by plotting total calcium against the respective total serum protein content in cases of hepatic cirrhosis, in most instances of the Laennec type. The serum albumin may be considerably decreased in cirrho- sis of the liver, as is well known, and some cases also show varying degrees of hyperglobulinemia (Table I).

The points representing our cases of hepatic cirrhosis do not fall along the straight line corresponding to Equation I. The discrepant relation of the 164 observations plotted in Figure 3 indicates that Equation $I$ is not generally valid over the range of variation in serum proteins, as has been assumed.

Calcium-protein relation in multiple myeloma, hyperphosphatemia and malnutritional hypoproteinemia; grounds for exclusion of these conditions. It has been known for some time (15) that in multiple myeloma hyperproteinemia and hypercalcemia may co-exist. Of 75 published 


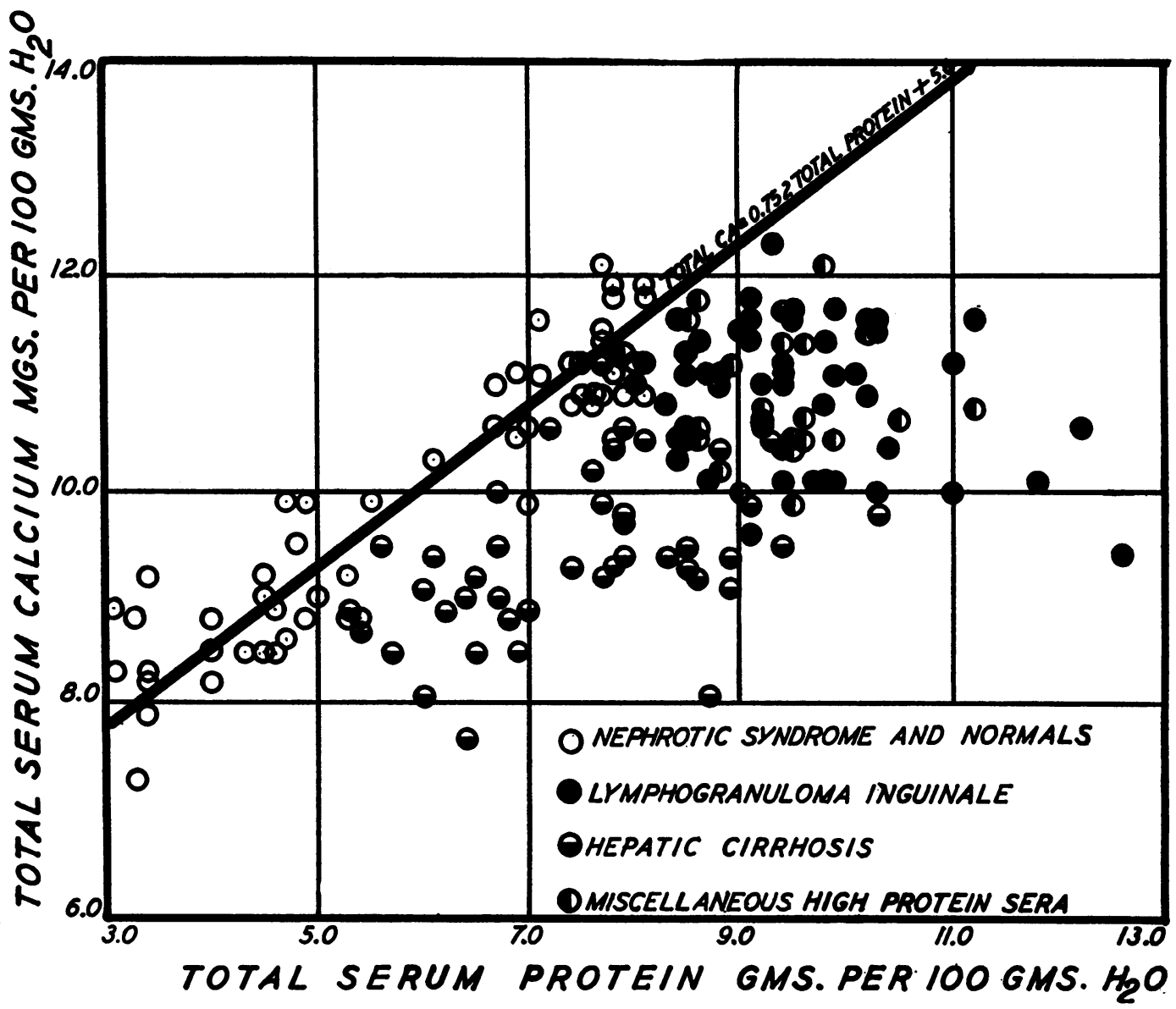

Fig. 3. Total Calcium Is Plotted Against Total Protein in 164 Sera Presenting Various Changes in Serum Proteins

There is no linear relation between total calcium and total protein.

cases of multiple myeloma in which both protein and calcium were determined (including 15 of our own), hyperproteinemia occurred in 43 of which 29 also presented hypercalcemia. The co-existence of hyperproteinemia and hypercalcemia in multiple myeloma has been regarded as evidence for the validity of Equation I in hyperproteinemia. But when total calcium is plotted against the respective total serum protein found in published cases of multiple myeloma (Figure 4), it is evident that the points so obtained do not fall along the line corresponding to Equation I. In fact, no linear relation can be made out between total calcium and total serum proteins.

Multiple myeloma is a disease characterized by extensive bone destruction and should be classified with conditions presenting a primary dis- turbance in calcium metabolism. Since, as stated at the outset, Equation I applies only where there is no primary disturbance in calcium metabolism, we regard discussion of the conformity or lack of conformity of such cases to Equation I as irrelevant; and feel justified in omitting our cases of multiple myeloma, by definition, from the data subjected to analysis.

The hypercalcemia observed in many cases of multiple myeloma (18) may well be due, not to hyperproteinemia (which may not be present in association with the hypercalcemia), but to the complication of co-existent bone destruction by neoplastic tissue; like the hypercalcemia found occasionally with metastatic osteolytic carcinoma, in which serum proteins are normal or low $(18,19)$. That the majority of cases of multiple myeloma 
TABLE I

Total protein, albumin and calcium content of 144 sera obtained from patients with diseases affecting the serum proteins; and of 20 normal sera

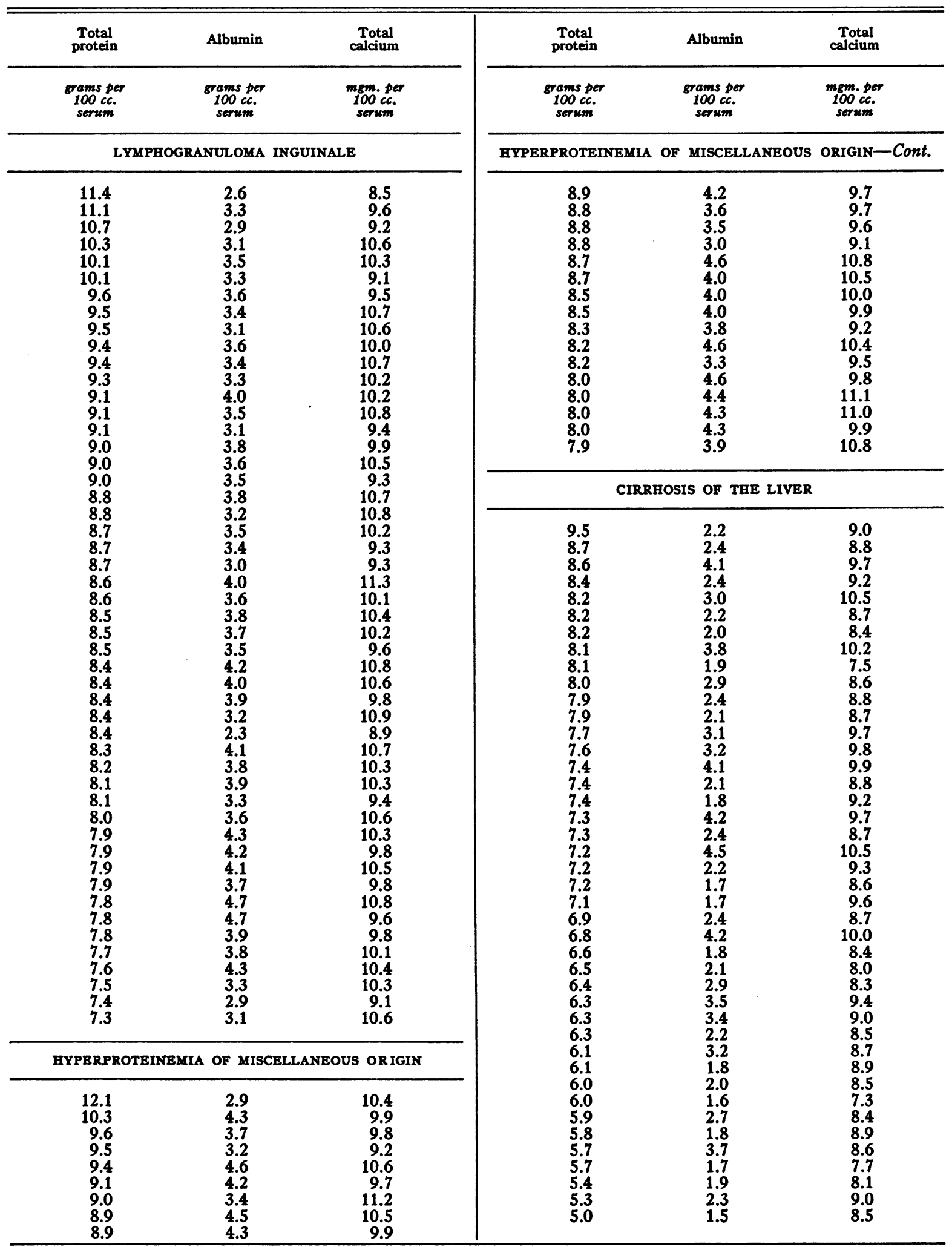


TABLE I-Continued

\begin{tabular}{|c|c|c|c|c|c|}
\hline $\begin{array}{c}\text { Total } \\
\text { protein }\end{array}$ & Albumin & $\begin{array}{c}\text { Total } \\
\text { calcium }\end{array}$ & $\begin{array}{c}\text { Total } \\
\text { protein }\end{array}$ & Albumin & $\begin{array}{l}\text { Total } \\
\text { calcium }\end{array}$ \\
\hline $\begin{array}{l}\text { grams per } \\
100 \text { cc. } \\
\text { serum }\end{array}$ & $\begin{array}{l}\text { grams per } \\
100 \text { cc. } \\
\text { serum }\end{array}$ & $\begin{array}{l}\text { mgm. per } \\
100 \text { cc. } \\
\text { serum }\end{array}$ & $\begin{array}{l}\text { erams per } \\
100 \text { cc. } \\
\text { serum }\end{array}$ & $\begin{array}{l}\text { grams per } \\
100 \text { cc. } \\
\text { serum }\end{array}$ & $\begin{array}{l}\text { mgm. per } \\
100 \text { cc. } \\
\text { serum }\end{array}$ \\
\hline \multicolumn{3}{|c|}{ “HEALED" NEPHROSIS } & \multicolumn{3}{|c|}{ NEPHROTIC SYNDROME-Continued } \\
\hline $\begin{array}{l}7.1 \\
6.7 \\
6.5 \\
6.3\end{array}$ & $\begin{array}{l}4.6 \\
4.4 \\
4.6 \\
3.9\end{array}$ & $\begin{array}{l}10.1 \\
10.4 \\
10.4 \\
10.4\end{array}$ & $\begin{array}{l}3.3 \\
3.2 \\
3.2\end{array}$ & $\begin{array}{l}1.5 \\
1.3 \\
1.1\end{array}$ & $\begin{array}{l}8.0 \\
8.1 \\
7.1\end{array}$ \\
\hline \multicolumn{3}{|c|}{ NEPHROTIC SYNDROME } & \multicolumn{3}{|c|}{ NORMAL SUBJECTS } \\
\hline $\begin{array}{l}5.8 \\
5.2 \\
5.1 \\
5.0 \\
5.0 \\
4.8 \\
4.7 \\
4.7 \\
4.5 \\
4.5 \\
4.3 \\
4.3 \\
4.1 \\
3.8 \\
3.8 \\
3.8 \\
3.8 \\
3.8 \\
3.3 \\
3.3 \\
\end{array}$ & $\begin{array}{l}3.2 \\
3.0 \\
2.3 \\
2.8 \\
1.8 \\
2.5 \\
2.5 \\
2.1 \\
3.4 \\
2.4 \\
2.0 \\
2.0 \\
2.2 \\
1.9 \\
1.8 \\
1.7 \\
1.5 \\
1.3 \\
2.0 \\
1.6 \\
\end{array}$ & $\begin{array}{l}9.8 \\
9.4 \\
8.4 \\
8.8 \\
8.4 \\
8.6 \\
9.5 \\
8.4 \\
8.2 \\
9.5 \\
8.6 \\
8.1 \\
8.1 \\
8.2 \\
8.5 \\
7.9 \\
8.2 \\
7.5 \\
8.9 \\
8.0\end{array}$ & $\begin{array}{l}7.6 \\
7.6 \\
7.6 \\
7.5 \\
7.4 \\
7.4 \\
7.3 \\
7.3 \\
7.3 \\
7.3 \\
7.2 \\
7.2 \\
7.2 \\
7.1 \\
7.0 \\
6.9 \\
6.7 \\
6.6 \\
6.5 \\
6.3\end{array}$ & $\begin{array}{l}4.9 \\
4.4 \\
3.8 \\
5.1 \\
5.0 \\
4.5 \\
5.1 \\
4.9 \\
4.8 \\
4.8 \\
5.0 \\
4.9 \\
4.8 \\
5.2 \\
4.7 \\
4.6 \\
4.6 \\
4.5 \\
4.0 \\
4.5\end{array}$ & $\begin{array}{r}10.9 \\
11.0 \\
10.2 \\
10.5 \\
10.2 \\
10.6 \\
11.0 \\
9.9 \\
11.0 \\
10.5 \\
11.3 \\
10.8 \\
10.7 \\
10.1 \\
10.5 \\
10.5 \\
10.9 \\
9.3 \\
9.9 \\
10.0\end{array}$ \\
\hline
\end{tabular}

presenting hyperproteinemia also exhibit hypercalcemia may mean only that myelomatosis severe enough to cause hyperproteinemia is likely to be extensive enough to produce widespread skeletal damage, resulting in hypercalcemia. An absolute increase in protein-bound calcium demonstrated by ultrafiltration in some cases of multiple myeloma occurs, apparently, only in cases presenting hypercalcemia, and then irrespective of whether or not the serum protein content is increased (6). We have suggested elsewhere (6) that this increase in protein-bound calcium is a result, not the cause of the hypercalcemia; a result of the influx of $\mathrm{Ca}^{++}$caused by bone destruction, with reestablishment of equilibrium between these two fractions at higher levels of both ionized and protein-bound calcium. Moreover, it seems likely that, for reasons stated later, most of the increased protein-bound calcium in multiple myeloma presenting both hyperproteinemia and hypercalcemia is calcium bound by albumin; and little calcium is bound by the euglobulin increment usually responsible for the hyperproteinemia.

Cases of hyperphosphatemia are excluded because hyperphosphatemia, as is well known, depresses the total calcium content of the blood by mechanisms not directly dependent upon the serum proteins. The presence of hyperphosphatemia lowers the $\mathrm{Ca}^{++}$concentration and disturbs the equilibrium between $\mathrm{Ca}^{++}$and protein-bound calcium, apparently in part, at least, through the formation of non-diffusible (colloidal) calcium phosphate complexes. Peters and Eiserson (4) have suggested an empirical equation relating calcium to total protein and inorganic phosphorus. We have not attempted to formulate such a more general equation from our data, however, but have included in Table I only sera containing 2.5 to $5.0 \mathrm{mgm}$. inorganic phosphorus per $100 \mathrm{cc}$. serum.

In our cases of malnutritional hypoproteinemia, points obtained by plotting total calcium against 


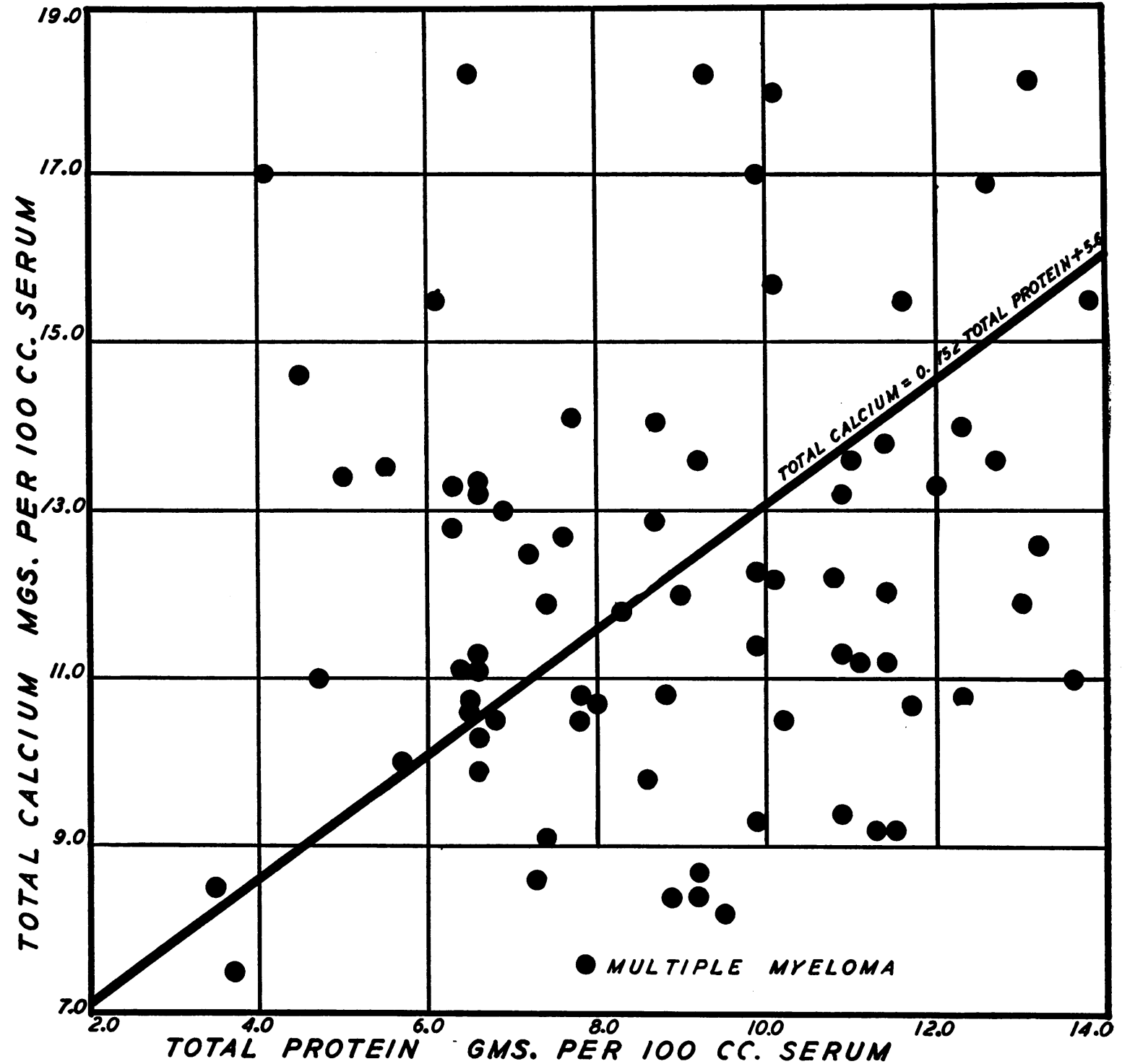

Fig. 4. Relation of Total Calcium to the Respective Total Protein Content in 75 Observations on MulTIPle Myeloma, as Reported in the Literature

the respective total protein content fall consistently below the straight line corresponding to Equation I, the divergency tending to be more marked where the total protein content is very low. Decreased $\mathrm{Ca}^{++}$may account for this discrepancy. It is known that, associated with hypoproteinemia due to malnutrition, not only the protein-bound but also the $\mathrm{Ca}^{++}$concentration may fall-to such low levels that symptoms of tetany may appear. In a broad sense, this condition constitutes a primary disturbance in calcium metabolism in that the intake or absorption of calcium is abnormal. At any rate, the concentration of $\mathrm{Ca}^{++}$ cannot be assumed to be within normal limits in malnutritional hypoproteinemia, and we have excluded our cases from the data subjected to analysis.

Cases with a primary disturbance in calcium metabolism, with hyperphosphatemia and with malnutritional hypoproteinemia are excluded, then, on the common ground that in these conditions, the concentration of $\mathrm{Ca}^{++}$does not remain within normal limits. It is essential that the $\mathrm{Ca}^{++}$ concentration remain relatively constant because 
in this, as in previous empirical attempts to obtain a quantitative expression of the relation of serum calcium to serum proteins, the effect of varying serum proteins on the total calcium content of the serum was considered. Since only part of the total serum calcium is bound to protein, this approach is possible only under conditions in which that fraction of the total calcium which is not bound to protein (chiefly $\mathrm{Ca}^{++}$) remains constant. Expressed in terms of Equation I, $b$ must remain fixed.

This condition is approximated in normal and nephrotic sera, which have been shown by various investigators to maintain a reasonably constant diffusible calcium content at a mean level of about $5.8 \pm 0.2 \mathrm{mgm}$. calcium. This condition obtains also in hyperproteinemia due to lymphogranuloma inguinale (6) and in other diseases included in our series of cases (34).

In primary disturbances in calcium metabolism, in hyperphosphatemia and in severe malnutrition, however, gross fluctuations in the concentration of $\mathrm{Ca}^{++}$occur, for reasons already stated. Such fluctuations in the concentration of $\mathrm{Ca}^{++}$affect not only the level of ionized calcium but also the amount of calcium bound to protein; since these two fractions tend to maintain an equilibrium at levels which are predictable, as McLean and Hastings (5) have shown, from mass law considerations. Expressed in terms of Equation I, $m$ being a function of $b$ (see derivation from the mass law), $m$ assumes different values as $b$ varies, and $m$ is fixed only so long as $b$ is fixed. Empirical constants for the calcium-binding properties of the serum proteins can be expected to apply, therefore, only under conditions in which the concentration of $\mathrm{Ca}^{++}$is the same, i.e., within normal limits.

We have not attempted to estimate proteinbound calcium more directly by ultrafiltration (except in a few instances) or by the McLean and Hastings' (16) frog-heart method for direct estimation of $\mathrm{Ca}^{++}$. An attempt was made to calculate $\mathrm{CaProt}$. and $\mathrm{Ca}^{++}$from the total calcium and total protein (5) or albumin and globulin content (17) of the serum. But this approach was abandoned when it was found that in sera with marked hyperglobulinemia due to lymphogranuloma inguinale, calculated values for $\mathrm{Ca}^{++}$were considerably lower than the diffusible calcium (6). In extreme cases, the calculated $\mathrm{Ca}^{++}$concentration was so low as to be within the range of tetany, of which our cases show no signs clinically. As suggested elsewhere (14), constants for $B$ globulin and $\mathrm{pK}_{\mathrm{C}_{\mathrm{a}} \mathrm{P}_{\text {rot. }} \text { derived from normal serum globulin }}$ may not be applicable to globulins occurring in marked hyperglobulinemia.

\section{DISCUSSION}

Our results are in accord with the view that a direct linear proportionality between total serum calcium and total serum protein, expressed by Equation I, exists in nephrotic and normal sera, from which Equation I was originally derived. When applied to hyperproteinemia, however, Equation I leads to gross discrepancies between calculated and observed calcium values (Figures 2 and 3 ) ; because such application involves extrapolation on the assumption, apparently incorrect, that the straight line relation found in hypoproteinemia holds at elevated serum protein levels.

In Equation I, the common factor $m$ is used to express the amount of calcium bound per gram of total serum proteins, although the serum proteins are known to be composed of several more or less discrete protein fractions. A common factor may be so employed if the ratio of the respective serum protein fractions to each other remains fixed in diseases affecting the total protein level of the serum; or, should these ratios vary, if the amount of calcium bound per gram of the several serum proteins is approximately the same.

It is now well established that the ratio albumin:total globulin does not remain constant as the total serum protein content rises above or falls below normal limits. Hypoproteinemia, as is well known, is due wholly or in large part to decreased serum albumin; whereas hyperproteinemia appears to be due invariably to increased serum globulins $(6,14,20)$. Moreover, the several globulins present in serum (as defined by fractional salting out with sodium sulfate) are themselves disproportionately affected when the totai globulin content rises. The euglobulin fraction, as defined by Howe's method, almost invariably constitutes most of the globulin increment; often in association with a more or less significant rise in the pseudoglobulin I fraction, as defined by Howe's method. The pseudoglobulin II fraction, however, so far as we could determine $(14,34)$, 
appears to remain within the limits observed in normal serum, despite marked elevations in total globulin content. Thus, while the euglobulin fraction, as defined by Howe's method, often comprises 20 per cent or less of the total globulin in normal serum, it may compose 50 per cent or more of the total globulin in hyperglobulinemia; whereas the pseudoglobulin II fraction, as defined by Howe's method, makes up a third or more of most normal serum globulins, but falls to as low as 15 per cent or less of the total serum globulins in marked hyperglobulinemia.

As to the amount of calcium bound specifically to the several serum protein fractions, nothing definite is known because the results obtained by different methods are conflicting. The prevailing impression, derived chiefly from observations made in various clinical conditions, appears to be in accord with the view expressed by Schmidt and Greenberg (11) that protein-bound calcium is "very largely united to albumin." Similar conclusions were reached by Csapó and Faubl (21), who found less calcium carried down by the globulin fraction precipitated by half-saturated ammonium sulfate than that carried down with the albumin fraction. The results of ultrafiltration experiments with graded membranes have been interpreted $(22,23)$, in fact, as indicating that all protein-bound calcium is bound solely to albumin. On the other hand, dialysis experiments carried out with normal serum globulin by Loeb (24) clearly indicate that normal serum globulin binds calcium. That normal serum globulin binds a significant amount of calcium was confirmed, among others, by McLean and Hastings (5), who give the following distribution of calcium fractions as typical where the total protein content is 7.0 per cent and the $A / G$ ratio is 1.8 :

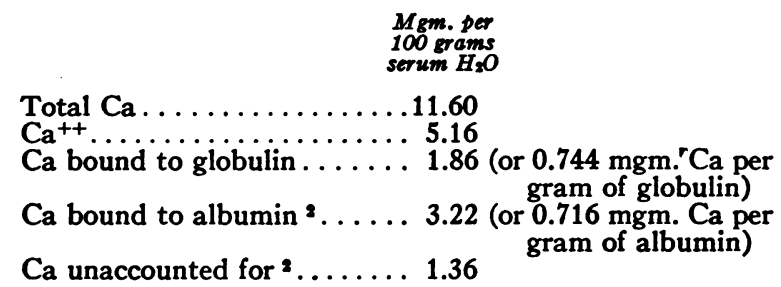

2 McLean and Hastings point out that serum albumin tends to lose some calcium-binding capacity during purification; hence the figure for albumin should be regarded as minimal and that for $\mathrm{Ca}$ unaccounted for as maximal.
As will be apparent subsequently, these conflicting results are not mutually exclusive but may well be due, in part, to the heterogeneous and varying composition of the total serum globulin fraction in normal serum and in hyperglobulinemia.

So far as our own results are concerned, if the several serum protein fractions bound approximately the same amount of calcium per gram, Equation I should give satisfactory agreement between observed and calculated calcium values over the range of variation in serum proteins; whereas gross discrepancies occur (Figures 2 and 3 ). Examination of Figure 3 reveals that the discrepant points are not erratically distributed but, with few exceptions, lie below the straight line corresponding to Equation I; i.e., the discordant sera consistently contain less calcium than that calculated from their total protein content by Equation I. It is further apparent (Table I, Figures 2 and 3 ) that the discrepant sera are, with few exceptions, those with increased globulin content, irrespective of etiology; i.e., the observed calcium content of most sera with marked hyperglobulinemia is significantly lower than that calculated from their total protein content. This generalization appears to hold whether the increase in serum globulins results in hyperproteinemia (as in lymphogranuloma inguinale) or whether (as in some cases of hepatic cirrhosis) the total protein remains within normal limits because of very low albumin levels. The serum globulin content was within normal limits in our cases with the nephrotic syndrome, in which agreement with Equation I was satisfactory.

That the observed calcium in hyperglobulinemia was lower than predicted was not due to hyperphosphatemia, which was not present in these sera; nor to a decrease in the $\mathrm{Ca}^{++}$fraction, which was shown to be within normal limits by ultrafiltration (6) and by the absence of clinical signs of tetany. The discrepancy results because, in hyperglobulinemia, the amount of calcium bound to protein is consistently less than that predicted by Equation I from the total protein content. We infer that the total globulin fraction in hyperglobulinemia binds less calcium than indicated by the several constants proposed in Equation I for $m$ (6).

In Figure 5, we have plotted total calcium against the respective total globulin content of 


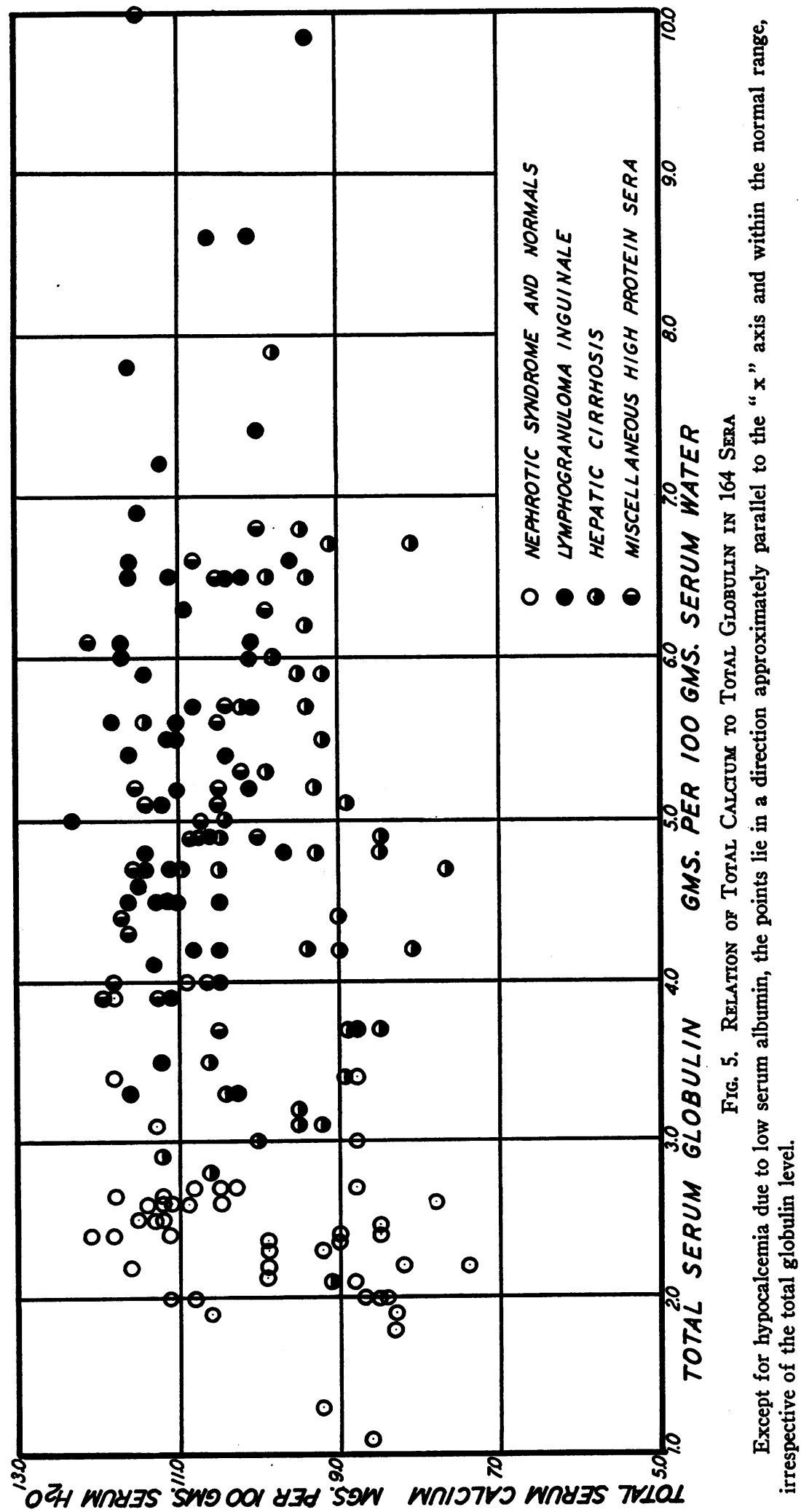


our sera. If the protein-bound calcium content of these sera depended chiefly upon their globulin content, the points would fall along a line having a definite slope. We find, on the contrary, that the points fall in a direction approximately parallel to the " $x$ " axis-the correlation between total calcium and total globulin appears to be almost zero. Apart from some low values due to decreased serum albumin content, the total calcium remains within normal limits, irrespective of the total globulin level. The graph suggests that the amount of calcium bound to globulin is either insignificant or small and constant throughout. Figure 5 is not wholly satisfactory, however, because though three variables are involved, only two can be plotted; and more precise statistical analysis necessitates some modification of this initial impression.

In Figure 6, we have plotted total calcium against the respective albumin content of our sera.
The points show a definite trend with a sharp slope. The graph indicates that most of the protein-bound calcium is bound to albumin. That not all the protein-bound calcium is bound to albumin, however, is suggested by the following two observations.

1. It is apparent upon inspection of Figure 6 that the intercept on the " $y$ " ( $\mathrm{Ca}$ ) axis of the trend shown by these points is significantly higher than 5.8 (the mean of observed values for diffusible calcium or $\left.\mathrm{Ca}^{++}\right)$; i.e., a small, constant calcium fraction is bound to protein but not to albumin. Since there appears to be no constant, systematic error in determining either calcium or albumin, and since evidence for a diffusible, nonionized calcium fraction in significant amount is lacking, we infer that this small, constant calcium fraction is bound to globulin. The amount so bound was estimated more accurately by deriving a linear equation from our normal and nephrotic

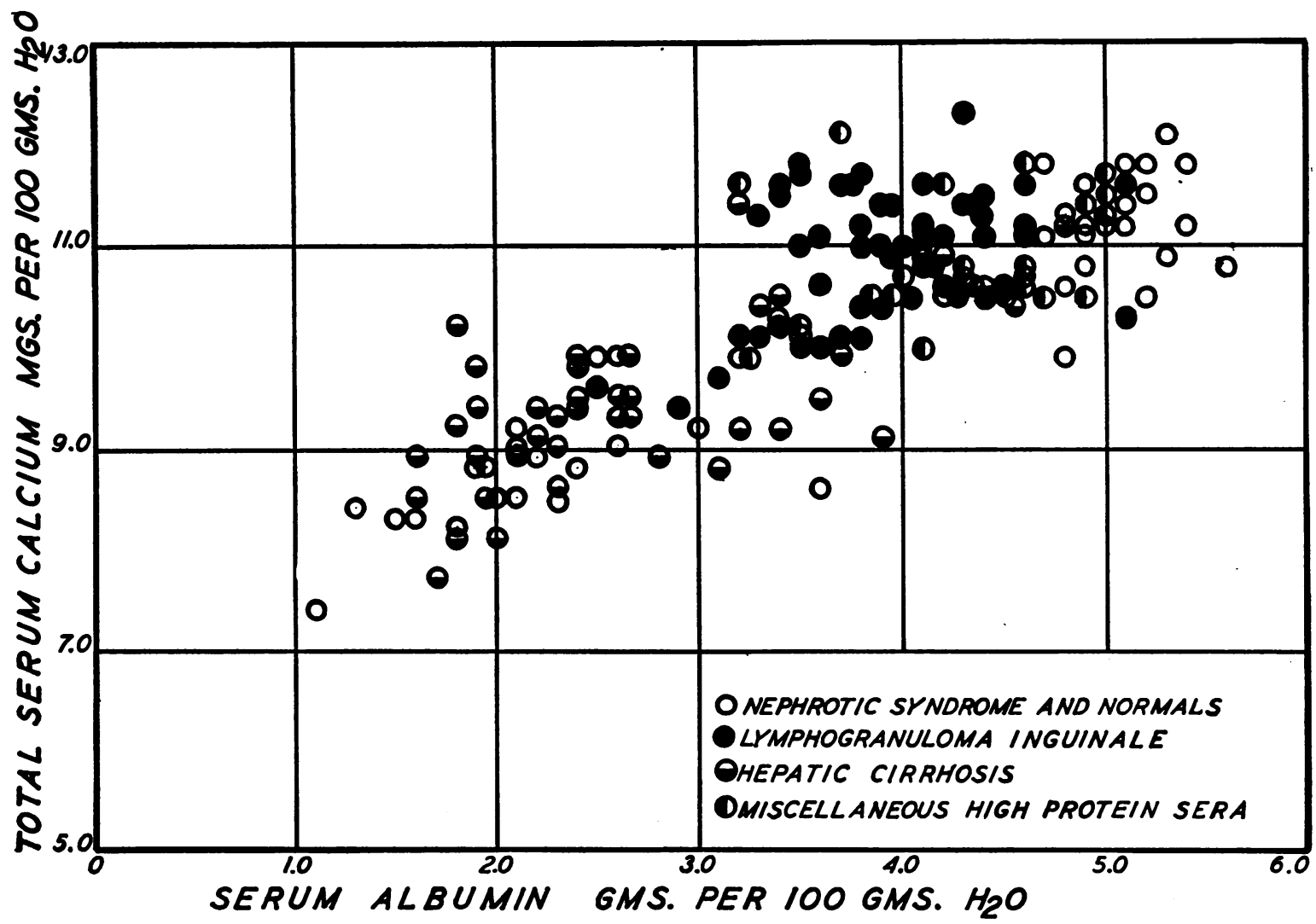

Fig. 6. Relation of Total Calcium to Albumin in 164 Sera

The points show a definite trend with sharp slope, indicating that most of the protein-bound calcium is bound to albumin. 
sera by the method of least squares. Calcium is expressed in milligrams, albumin in grams per 100 grams serum water in the equation so obtained:

$$
\text { Total } \mathrm{Ca}=0.83 \text { albumin }+7.0 \text {. }
$$

By subtracting 5.8 from 7.0, the intercept on the " $y$ " axis, we obtain 1.2 as an approximation of the mean amount of calcium bound by this globulin fraction, designated " globulin fraction II."

2. It is further apparent upon inspection of Figure 6 that the majority of points corresponding to lymphogranuloma inguinale and other conditions with marked hyperglobulinemia fall above the general linear trend. Statistical analysis reveals that this deviation becomes appreciable when the total globulin content exceeds approximately 4.0 per cent ; and that the deviation is roughly proportional to the degree of hyperglobulinemia. We infer that, in hyperglobulinemia, a small but increasingly significant amount of calcium is bound to the globulin increment responsible for the hyperglobulinemia. This globulin, which we shall refer to as "globulin fraction I," is presumably chiefly euglobulin, partly pseudoglobulin I, as defined by Howe's method. Our calculations indicate that this fraction binds approximately 0.1 to $0.2 \mathrm{mgm}$. calcium per gram of globulin.

To sum up then, analysis of our data suggests that the total serum calcium is composed of at least four distinct fractions: 1 , Calcium bound to and proportional to the albumin fraction; 2, calcium bound to a globulin fraction which remains relatively constant in amount irrespective of the total globulin level; 3 , calcium bound in small amount to another globulin fraction, increasing with the total globulin level and becoming significant in marked hyperglobulinemia; 4, calcium not bound to protein, relatively constant because gross fluctuations are excluded by definition. These fractions are represented in the following general regression equation (12):

Total $\mathrm{Ca}=-m_{1} \cdot$ albumin $+m_{2} \cdot$ "globulin fraction II" $+m_{3} \cdot$ "globulin fraction I" + $b$. IV

Statistical analysis of our own and published data suggests that these constants have the following limiting values: Where $b=5.8 \pm 0.2 \mathrm{mgm}$. Ca per 100 grams of serum $\mathrm{H}_{2} \mathrm{O}, m_{1}$ is of the order 0.7 to $0.9 \mathrm{mgm}$. Ca per gram of albumin; the product $m_{2} \cdot$ "globulin fraction II" is a constant of the order $1.0 \pm 0.5 \mathrm{mgm}$. Ca per 100 grams of serum $\mathrm{H}_{2} \mathrm{O} ; m_{3}$ is of the order 0.1 to $0.2 \mathrm{mgm}$. Ca per gram " globulin fraction I" where " globulin fraction I" is defined arbitrarily as all globulin in excess of 3.0 grams of total globulin.

Values calculated for total calcium by Equation IV, using constants within the limits specified, approximate observed total calcium more closely over the range of variation in serum proteins, than do values calculated by Equation I. This is illustrated in Figure 7 where we have plotted mean ratios, calculated total serum calcium:observed total serum calcium, against the total protein content. $^{8}$ So plotted, a generally valid equation for calculating total calcium will yield points which fall along a straight line at or near 1.00 , with zero slope. Equation IV appears to satisfy these criteria. Equation I, on the other hand, yields points diverging progressively upward with increasing total protein (globulin) content.

Figure 7 also illustrates the results obtained with two other general regression equations subjected to statistical analysis (12). In the first of these, the term " $m$-total protein" in Equation I is expanded to allow for different calcium-binding properties of the albumin and total globulin fractions :

Total Ca $=m_{1} \cdot$ albumin $+m_{2} \cdot$ total

$$
\text { globulin }+b \text {. } \mathrm{V}
$$

In the other, all protein-bound calcium is assumed to be bound to albumin, as suggested by Bendien and Snapper (22):

$$
\text { Total } \mathrm{Ca}=m \cdot \text { albumin }+b \text {. }
$$

Both these formulae, like Equation IV, give predicted total calcium values for nephrotic and normal sera quite as satisfactory as those obtained with Equation I (12). And both formulae, like Equation IV, may be derived from general mass

\footnotetext{
8 The ratio, total calcium calculated : total calcium observed, was first calculated for each serum, using Equation IV with the constants indicated in the legend of Figure 7. Then the sera were grouped accordinig to total protein content, expressed in grams per 100 grams of serum $\mathrm{H}_{2} \mathrm{O}: 3.1$ to 6.0 grams, 28 observations; 6.1 to 8.0 grams, 50 observations (20 normal sera, 30 pathological) ; 8.1 to 10.0 grams, 68 observations; 10.1 or more grams, 18 observations. The mean ratio for the sera in each group was then calculated. The process was repeated for Equations I, V and VI, using the respective constants indicated in the legend of Figure 7.
} 


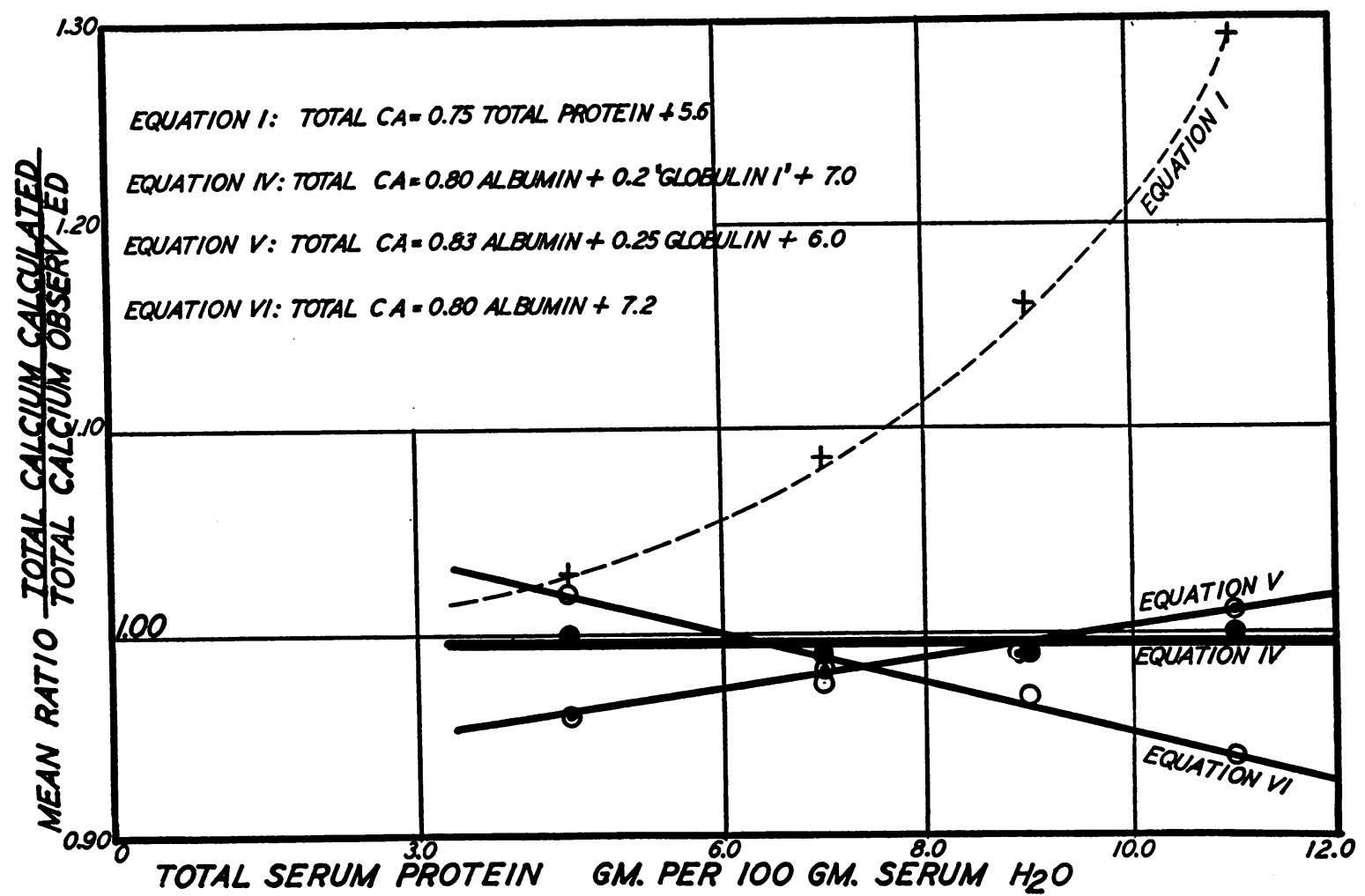

Fig. 7

The mean ratio, calculated total calcium: observed total calcium, is approximately 1.00 throughout the range of variation in serum proteins when Equation IV is used. Equation I gives increasingly divergent results in hyperglobulinemia. Equation V has a positive slope, Equation VI has a negative slope.

law equations by methods analogous to those used in the derivation of Equation I (see page 903). But as shown in Figure 7, neither Equation V nor Equation VI gives as satisfactory agreement between calculated and observed total calcium in both low and high protein sera as does Equation IV. The points corresponding to Equation V have a definite positive slope because of discrepancies arising from the heterogeneous composition of the total globulin fraction, as suggested elsewhere $(6,12)$. The points corresponding to Equation VI have a definite negative slope, presumably because the globulin fraction does bind some calcium. ${ }^{4}$

4 Of course, the position and slope of the lines corresponding to these equations depend, in part, upon the constants employed. For Equation I, means of the published values for $m$ and $b$ were used as most representative. For Equations V and VI, we used constants giving the best fit, as determined by the method of least squares. Results obtained by trial of other constants in Equations
"Globulin fraction II," which is relatively constant in amount in all sera irrespective of total globulin content, resembles in this respect the pseudoglobulin II fraction, as determined by Howe's method. Further, the amount of "globulin fraction II" present in serum approximates that of pseudoglobulin II, as we could find no evidence of decreased "globulin fraction II" in sera containing as little as 1.5 grams total globulin. Since the product $m_{2} \cdot$ "globulin fraction II" is approximately $1.0 \pm 0.5 \mathrm{mgm}$. $\mathrm{Ca}$, this implies

I, V and VI (12) show that the slopes change in degree but not in direction.

The dispersion obtained with Equation IV using the constants indicated in Figure 7 is shown elsewhere by means of a scatter diagram (12). The standard error of estimate is $0.575 \mathrm{mgm}$. Ca. Sixty-five per cent of the ratios are within \pm 5 per cent of 1.00 ; in 20 instances the ratio exceeded 1.05, of which 5 exceeded 1.10 ; in 32 instances the ratio was less than 0.95 , of which 7 were less than $\mathbf{0 . 9 0}$. 
that "globulin fraction II" binds more calcium per gram than does albumin.

In connection with " globulin fraction I," globulins with isoelectric zones at $\mathrm{pH}$ approaching that of serum have been isolated repeatedly from the sera of immunized animals $(25,26,27,28)$. Evidence for the existence of such a globulin in hyperglobulinemia due to kala-azar has been offered by Chopra and Chaudhury (29). We have called attention elsewhere (14) to certain discrepancies in the acid-base equivalence of the blood in hyperglobulinemia (of which the discrepancies in calcium here described are a special case) as indicating the existence of such a globulin fraction.

The inference that the total globulin in normal and pathological sera is composed of varying mixtures of two or more globulin fractions which bind different amounts of calcium may explain a discrepancy already referred to: the apparent conflict between the view that the protein-bound calcium in serum depends chiefly upon the serum albumin content and the repeatedly demonstrated binding of considerable amounts of calcium by normal serum globulin. In hyperglobulinemia, the total globulin fraction appears to be composed largely of a globulin which binds little calcium ("globulin fraction I"); whereas a large proportion of normal serum globulin consists of a globulin ("globulin fraction II") which binds appreciable amounts of calcium.

\section{SUM MARY}

1. The relation of total serum calcium to total serum protein and to the several protein fractions was studied by graphic and statistical analysis of 164 observations on 128 cases. The total protein content of these sera, expressed in grams per 100 grams of serum $\mathrm{H}_{2} \mathrm{O}$, was: 3.1 to 6.0 grams, 28 observations; 6.1 to 8.0 grams, 50 observations (20 normal, 30 pathological sera) ; 8.1 to 10.0 grams, 68 observations; 10.1 or more grams, 18 observations. Cases with a primary disturbance in calcium metabolism (including multiple myeloma), with hyperphosphatemia or with malnutritional hypoproteinemia were excluded.

2. It was found that while total calcium is directly proportional to total protein in nephrotic and normal sera, no such relation obtains in hyperproteinemia. Apart from some cases of multiple myeloma, where bone destruction is the prob- able cause of hypercalcemia, the total serum calcium does not rise in hyperproteinemia but is maintained at normal levels. Equations relating total calcium to total serum protein do not hold when hyperglobulinemia is present. This discrepancy results, apparently, because the globulin increment in hyperglobulinemia binds very little calcium.

3. Analysis of our data suggests that the total serum calcium is composed of at least four fractions: 1 , Calcium bound to and proportional to albumin; 2, calcium bound to a globulin fraction which remains relatively constant in amount irrespective of the total globulin level; 3 , calcium bound in small amount to another globulin fraction, increasing with the total globulin level but becoming significant only in marked hyperglobulinemia; 4, calcium not bound to protein, relatively constant because cases with gross fluctuations are excluded by definition. (Calcium not bound to protein is itself subdivided into an ionized and a small non-ionized fraction.)

4. A regression equation relating total calcium to albumin and two arbitrary globulin fractions is presented in the following general form:

Total $\mathrm{Ca}=m_{1} \cdot$ albumin $+m_{2} \cdot$ "globulin

fraction II" $+m_{3} \cdot$ " globulin fraction I " $+b$.

The several constants in this equation appear to have the following limiting values: Where $b=$ $5.8 \pm 0.2$ mgm. $\mathrm{Ca}$ per 100 grams serum $\mathrm{H}_{2} \mathrm{O}$, $m_{1}$ is of the order 0.7 to $0.9 \mathrm{mgm}$. Ca per gram of albumin; the product $m_{2} \cdot$ "globulin fraction II" is a constant of the order $1.0 \pm 0.5 \mathrm{mgm}$. Ca per 100 grams of serum $\mathrm{H}_{2} \mathrm{O} ; m_{3}$ is of the order 0.1 to $0.2 \mathrm{mgm}$. Ca per gram "globulin fraction I," where "globulin fraction I" is arbitrarily defined as all globulin in excess of 3.0 grams of total globulin.

5. This equation appears to be more generally valid over the range of variation in serum proteins (within the limitations prescribed) than are equations relating total calcium to total protein, to albumin and total globulin, or to albumin alone.

\section{BIBLIOGRAPHY}

1. Salvesen, H. A., and Linder, G. C., Observations on the inorganic bases and phosphates in relation to the protein of blood and other body fluids in Bright's disease and in heart failure. J. Biol. Chem., 1923, 58, 617. 
2. Marrack, J., and Thacker, G., The state of calcium in body fluids. Biochem. J., 1926, 20, 580.

3. Hastings, A. B., Murray, C. D., and Sendroy, J., Jr., Studies of the solubility of calcium salts. I. The solubility of calcium carbonate in salt solutions and biological fluids. J. Biol. Chem., 1927, 71, 723.

4. Peters, J. P., and Eiserson, L., The influence of protein and inorganic phosphorus on serum calcium. J. Biol. Chem., 1929, 84, 155.

5. McLean, F. C., and Hastings, A. B., The state of calcium in the fluids of the body. I. The conditions affecting the ionization of calcium. J. Biol. Chem., 1935, 108, 285.

6. Gutman, A. B., and Gutman, E. B., Calcium-protein relation in hyperproteinemia: Total and diffusible serum calcium in lymphogranuloma inguinale and myeloma. Proc. Soc. Exper. Biol. and Med., 1936, 35, 511.

7. Greenberg, D. M., and Greenberg, L. D., Is there an unknown compound of the nature of calcium citrate present in the blood? J. Biol. Chem., 1932, $99,1$.

8. McLean, F. C., and Hastings, A. B., Clinical estimation and significance of calcium-ion concentrations in the blood. Am. J. M. Sc., 1935, 189, 601.

9. Peters, J. P., and Van Slyke, D. D., Quantitative Clinical Chemistry. Volume I. Interpretations. Williams and Wilkins Co., Baltimore, 1931, p. 814.

10. Flood, C. A., Gutman, E. B., and Gutman, A. B., Phosphatase activity, inorganic phosphorus and calcium of serum in disease of liver and biliary tract. A study of one hundred and twenty-three cases. Arch. Int. Med., 1937, 59, 981.

11. Schmidt, C. L. A., and Greenberg, D. M., Occurrence, transport and regulation of calcium, magnesium and phosphorus in the animal organism. Physiol. Rev., 1935, 15, 297.

12. Gutman, A. B., and Gutman, E. B., An empirical regression equation relating total serum calcium to serum albumin and globulins. Proc. Soc. Exper. Biol. and Med., 1937, 36, 527.

13. Williams, R. D., and Gutman, A. B., Hyperproteinemia with reversal of the albumin: globulin ratio in lymphogranuloma inguinale. Proc. Soc. Exper. Biol. and Med., 1936, 34, 91.

14. Gutman, A. B., Gutman, E. B., Jillson, R., and Williams, R. D., Acid-base equivalence of the blood in diseases associated with hyperglobulinemia; with special reference to lymphogranuloma inguinale and multiple myeloma. J. Clin. Invest., 1936, 15, 475.

15. Perlzweig, W. A., Delrue, G., and Geschickter, C., Hyperproteinemia associated with multiple myelomas. Report of an unusual case. J. A. M. A., 1928, 90, 755.

16. McLean, F. C., and Hastings, A. B., A biological method for the estimation of calcium ion concentration. J. Biol. Chem., 1934, 107, 337.

17. Weir, E. G., and Hastings, A. B., The ionization constants of calcium proteinate determined by the solu- bility of calcium carbonate. J. Biol. Chem., 1936, 114, 397.

18. Gutman, A. B., Tyson, T. L., and Gutman, E. B., Serum calcium, inorganic phosphorus and phosphatase activity in hyperparathyroidism, Paget's disease, multiple myeloma and neoplastic disease of the bones. Arch. Int. Med., 1936, 57, 379.

19. Robbins, C. L., and Kydd, D. M., A note on the metabolic criteria of hyperparathyroidism. J. Clin. Invest., 1935, 14, 220.

20. Wies, C. H., and Peters, J. P., The osmotic pressure of proteins in whole serum. J. Clin. Invest., 1937, 16, 93.

21. Csapó, J., and Faubl, J., Calciumgehalt der Serumeiweissfraktionen. Biochem. Ztschr., 1924, 150, 509.

22. Bendien, W. M., and Snapper, I., Untersuchungen über die Bindung der Kolloide des Serums mit Hilfe von Ultrafiltern erhöhter Durchlässigkeit. Biochem. Ztschr., 1933, 260, 105.

23. Schmitz, J. W., Over Den Toestand Van Het Calcium In Bloed En Serum. Jacob Van Campen, Amsterdam, 1937.

24. Loeb, R. F., The effect of pure protein solutions and of blood serum on the diffusibility of calcium. J. Gen. Physiol., 1926, 8, 451.

25. Felton, L. D., and Kauffmann, G., Certain characteristics of the water-insoluble protein of normal as compared with that of antipneumococcus horse serum. J. Immunol., 1933, 25, 165.

26. Reiner, H. K., and Reiner, L., The fractional precipitation of serum globulin at different hydrogen ion activities. Experiments with globulin obtained from normal and immune (antipneumococcus) horse serum. J. Biol. Chem., 1932, 95, 345.

27. Liu, S. C., Wu, H., and Chow, B. F., Isolation of a basic globulin fraction from normal and immune horse sera. Chinese J. Physiol., 1937, 11, 211.

28. Green, A. A., The euglobulins of serum and their combination with acid and base. J. Biol. Chem. (Proc.), 1937, 119, xxxix.

29. Chopra, R. N., and Chaudhury, S. G., Studies on the physical properties of different blood sera. V. Buffer action. Indian J. M. Research, 1933, 21, 25.

30. Clark, E. P., and Collip, J. B., A study of the Tisdall method for the determination of blood serum calcium with a suggested modification. J. Biol. Chem., 1925, 63, 461.

31. Folin, $\mathrm{O}$., and $\mathrm{Wu}, \mathrm{H}$., A system of blood analysis. J. Biol. Chem., 1919, 38, 87.

32. Howe, P., The determination of proteins in blooda micro method. J. Biol. Chem., 1921, 49, 109.

33. Bodansky, A., Phosphatase studies: 1. Determination of inorganic phosphate; Beer's law and interfering substances in the Kuttner-Lichtenstein method. J. Biol. Chem., 1932, 99, 197.

34. Gutman, A. B., and Gutman, E. B., Unpublished studies. 